\title{
Returning Water Data to Communities in Ndola, Zambia: A Case Study in Decolonising Environmental Science
}

\section{MANDO CHITONDO' AND KELLY DOMBROSKI ${ }^{2}$}

'Waterways Centre for Freshwater Management, University of Canterbury, New Zealand, ${ }^{2}$ Department of Geography, University of Canterbury Te Whare Wānanga o Waitaha, Private Bag 4800, Christchurch, New Zealand

Email: kelly.dombroski@canterbury.ac.nz

\begin{abstract}
Many scientific research projects carried out in developing countries gather data and fail to return any summary of the findings to the community that provided the data. Residents from communities experiencing water issues are therefore deprived of effective participation in the use of findings, since communities might be seen as only a source of data. Indigenous writers have revealed the injustice of this reality and have suggested that this is typical of colonial or 'colonising' research methods. It is concerning because accessing research knowledge encourages communities to examine their issues and empowers them to formulate solutions. Inspired by decolonising methodologies, we explored different 'decolonising' approaches to returning research findings to participant communities using the results of a recent water research project conducted in Ndola, Copperbelt Province, Zambia. In this case study, we describe participant communities experience regarding access to research findings and conclude that face-to-face discussion is the preferred approach to returning water research findings in Ndola.
\end{abstract}

\section{INTRODUCTION}

In many parts of the world, social scientists are required to submit their proposed research methods to ethics committees, which may recommend that they take back transcripts and summary reports to participants as a matter of course. Furthermore, a wide body of literature in the social sciences discusses the ethics and safety of researchers and participants in social science research projects, leading to a body of knowledge that scholars can access as they seek to plan their research methodologies. Topics covered in the literature include how to improve the methods being used, how to take into account individuals' effective participation and other key ethical considerations in research projects [ $\mathrm{I}-4]$. Yet to this day, natural scientists are usually not required to go through ethics committees if they are considering conducting research about water, volcanoes, reefs, soil, vegetation, or other nonhuman, non-animal entities. It is thus less common to seriously consider normal ethical issues in research design unless pushed to by circumstance and interaction, for example, after serious disasters [5]. This is especially problematic when there is a wide power differential between communities and researchers, for example, in cases where outsider or foreign researchers are working in communities of Indigenous peoples, or those largely made up of people living in poverty. For many Indigenous authors, these kinds of research relationships are a form of oppressive and exclusionary colonialism $[6,7]$. We tried to rectify or 'decolonise' water research in Zambia by exploring different methods for returning water data to Indigenous Zambian communities who had suffered years of non-participatory and extractive research methodologies. After due consideration, we have chosen to use the word 'decolonising' to describe what we are attempting to do because of the pattern of foreign outsiders coming in to Ndola to do water research very closely resembles colonial power relations, and we understand our role as researchers as being part of the struggle to get water scientists to honour the rights of (particularly Indigenous and colonised) communities from which water samples were taken.

Water research projects have been a feature in the Zambian scientific landscape for a long time, both before and after independence in 1964 . While the scientific findings from these water research projects have been used to set standards

Case Studies in the Environment, 2019 , pps. I-8. electronic ISSN 2473-95 10. () 2019 by the Regents of the University of California. All rights reserved. Please direct all requests for permission to photocopy or reproduce article content through the University of California Press's Reprints and Permissions web page, www.ucpress.edu/journals.php?p=reprints. DOI: https://doi.org/10.1525/cse.2018.001 552 
or guidelines to enable improved management of Zambia’s abundant water resources [8], about five million citizens still lack access to safe water for domestic needs [9]. Many research projects about water resources in Zambia are undertaken with participants from these communities with unsatisfactory water supplies. Yet even when the water resource knowledge produced from research includes water quality results, water quantity information, significant concerns, and mitigation options, researchers from other places generally have not shared these results with the Indigenous participant communities. Indeed, we found that in the three communities we worked with, the sharing of water quality results had never occurred, despite years of research being carried out by different scientists.

For us, this illustrates an essential oversight in ethical considerations that unfortunately is still neglected by many researchers. Our case study thus has two aims. The first of these is to describe the process of returning water data to three communities from a water project that (first author) Mando Chitondo assisted with 4 years ago in Ndola Zambia. The second is to report on the most appropriate methods for communicating and returning results to these three communities, with potential implications to other Indigenous groups.

\section{CASE EXAMINATION}

We designed our case study based on Mando's previous interactions with communities in Ndola, Zambia when she worked as a research assistant for a water-related research project conducted by Elizabeth Liddle [ 10 ]. Liddle's study assessed the state of the water quality, the challenges to provision, and the associated water development considerations in Ndola, Zambia. In our project, Mando first visited water quality experts at their workplaces as well as Liddle's research participants in their homes in Kabushi, Nkwazi, and Kaniki communities. In semistructured interviews, Mando asked 4 I participants about their experiences with water research projects and if they have had a researcher bring back water quality results after conducting research. ${ }^{1}$

I. Liddle's study was just one of many water quality studies carried out in the region. We are not here to critique Liddle's work, as she was indeed very pleased to be able to return the data to the community, and we are very grateful for her participation. In her case, as a Masters student based in New Zealand, it would have been near impossible for her to fund and carry out a second trip for returning data.
The Problem: Lack of Access to Water Testing Results

Produced by Research Projects

Despite being essential participants in the collection of water samples, both Zambian-based water experts and residents from local communities experiencing water issues reported that after outsider researchers completed their research, access to the knowledge produced is not subsequently ensured for Zambian researchers and the different Indigenous communities (Figure I).

Our interviewees expressed annoyance at the lack of access to the results of analyses of the water samples collected from their water sources:

Receiving water quality results from researchers after completion of research does not happen in this community. In fact, we have never had access to results before. (Man, aged 47)

Most residents said that they do not have much information about the quality of their water because it is difficult to know until analysis is done. Indeed many expressed anger and annoyance:

I do not know or do not have any idea about the quality of our water. You people [researchers] come to take samples and leave without coming back to tell us what may be in our water. Since no one returns, I assume that the water quality is good. How else do you expect us to know? So, I draw water from my well, but the water is sometimes not safe because we have incidences of diarrhoea. I expect to be informed when there are harmful contaminants in my well after analysis. However, this has never happened. You are the first person to come back to our community with results about samples collected from our water sources in the past. (Woman, aged 35)

Hence, many local people in Ndola do not want to participate in water research projects because they do not see any benefits in relation to addressing the water quality issues in their communities. This shows that the participant communities are being exploited by researchers who often use colonising research methodologies where the researcher benefits at the expense of participant communities in an unequal power relationship.

From the respondents' statements we have seen that residents from communities in Ndola unanimously want 

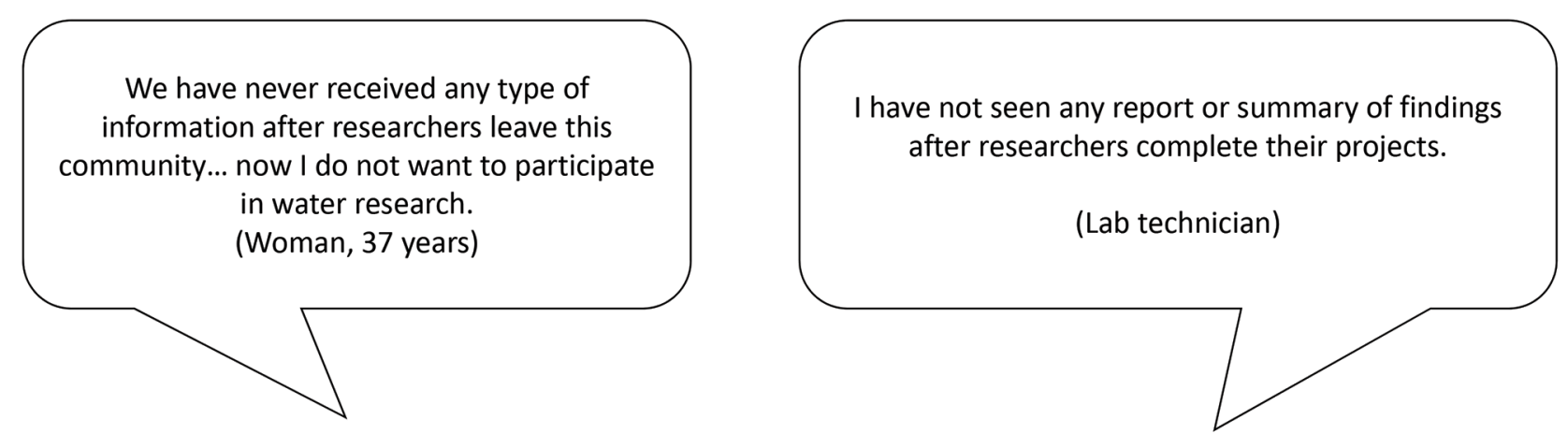

\section{Lack of access to water testing results}
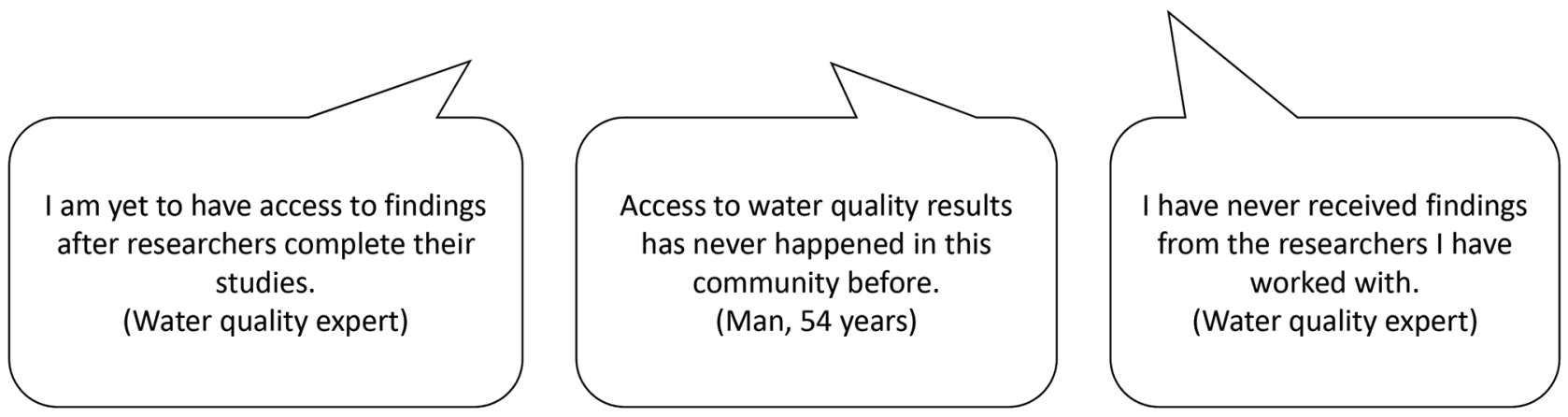

FIGURE 1. Lack of access to water testing results.

water quality results or findings returned to them. But what then, is the best approach to achieve this?

\section{Starting to Address the Problem: Developing Science} Communication Techniques for Returning Water Data

To help in developing an appropriate approach to returning the results, we drew on (first author) Mando Chitondo's knowledge of a water testing project as well as related community and cultural knowledge of Ndola and (second author) Kelly Dombroski's expertise in serving in (and at times, chairing) the University of Canterbury Human Ethics Committee (2015-2018), in addition to conducting participatory community research projects in Asia and Oceania. We also read and discussed the work of scholars seeking to decolonise methodology, in particular the work of Tuhiwai Smith [6] and Chilisa [7]. These scholars describe problematic instances where colonised communities have been subject to outsider-led research either on themselves or with their resources and environment without attention to their aspirations and needs. Tuhiwai Smith and Chilisa both insist that researchers should be sharing results with the participant communities at the end of the research project, and even more importantly, collaborating with communities to design appropriate research projects that serve community aspirations. They are not afraid to call inappropriate extractive research 'colonising' when it involves power differentials where one group of privileged people (often outsider, white academics) takes control of the knowledgemaking process in either the natural or social sciences.

After collating the experiences of Ndola residents and water quality workers, Mando developed science communication resources reporting the results of Liddle's study in the form of a video, a brochure, an oral presentation and a plan for an open discussion meeting. The communication resources included water quality results, significant concerns and mitigation options. Mando conducted three focus group meetings in Kabushi, Nkwazi, and Kaniki communities, inviting ten to twelve participants at each to comment on the use of video, brochure, presentation, and discussion methods.

Mando used a different order each time she shared the water resource information to ensure that the participants were not biased to a method due to the order used. As recommended in most social science ethics procedures, she used a language spoken as mother tongue by the focus group participants from the communities, known as Bemba. Figures 2 and 3 show the brochure used in Kaniki community, which is similar to those used in Kabushi and Nkwazi communities 


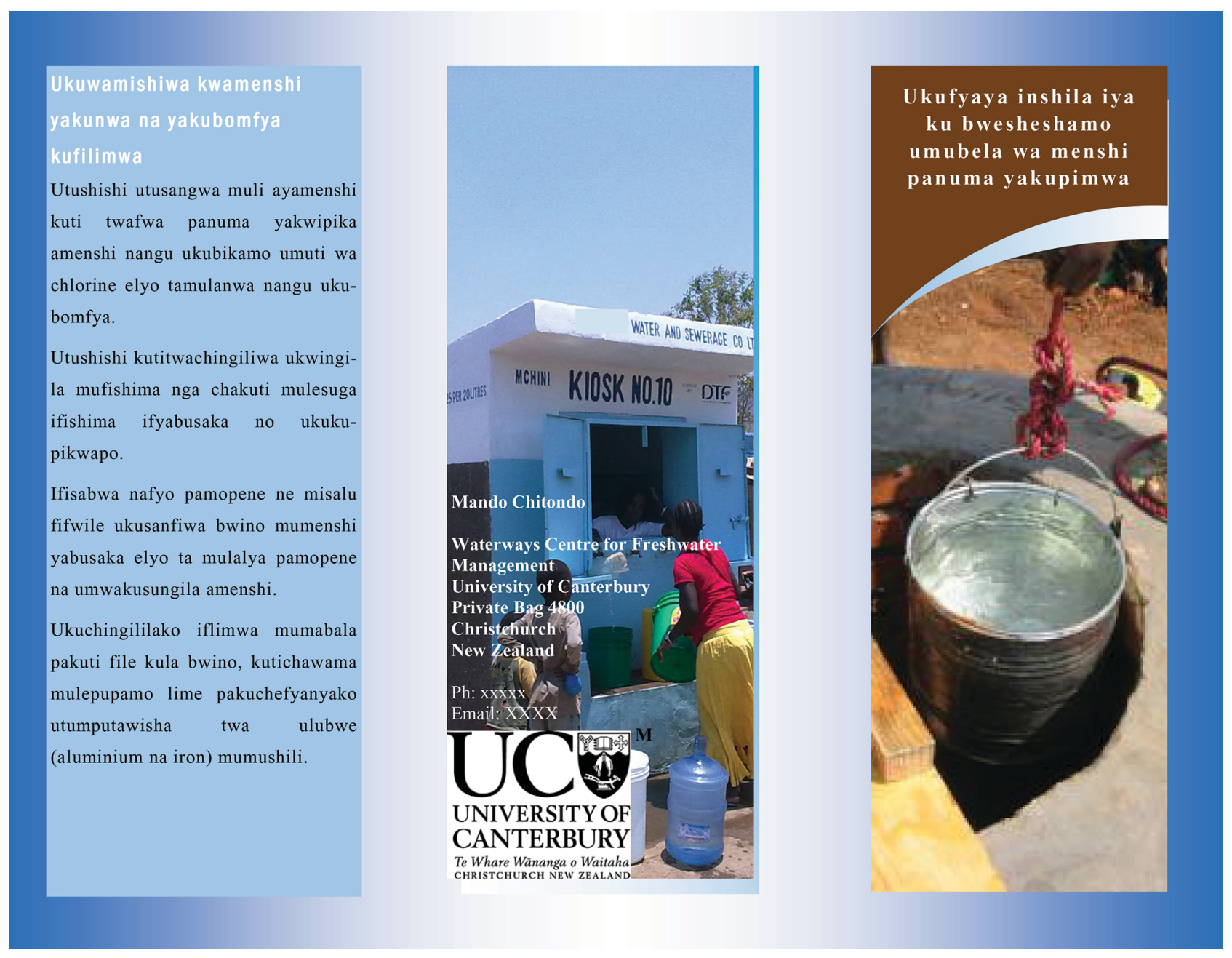

FIGURE 2. Front of Brochure used in Kaniki.

using the pertinent data collected by Liddle. Participants were keen to discuss the water results face-to-face and also commented that this was the first time they had access to water data despite years of water projects in the region.

\section{The Best Solution: Face-to-Face Approaches for Returning Water Data to Communities in Ndola}

The participant communities unanimously preferred face-toface discussion as the appropriate method for returning research findings because it allows the researcher and individuals to engage in dialogue (talking over the research findings from every angle), thus gaining a better understanding of their implications and to learn from each other. Face-to-face discussion is the appropriate method for sharing water resource knowledge with participant communities in Ndola, Zambia because they belong to tribes where oral communication is one of the traditional methods used to share or build knowledge.

According to the focus group participants, they

want and expect to have face-to-face discussions about an important topic like water issues and safeguarding people's health (Focus group I).

\section{They believed that}

Meeting face to face is traditionally appropriate and it is considered respectful to come back and discuss the results because it enables learning from each other (Focus group 3).

In this way, the researcher and communities can both benefit from research by fully understanding the water 


Kabushi ninchende mu Ndola, um-
wikala abantu ukufika kuli
Amenshi ya kunwa yantu ba bomfya
yantu bemba mufishima ifipi ne ifitali,
mukamana elyo na ku ma pompi
mumayanda.
Ifya fum ine
k wa me ns hi
Ifyafumine mukupimwa kwa ayamen-
shi fyakuti amenshi mukamana ka Ka-
fubu yalisankane na utunputawishya
twa ulubwe (aluminium na iron) na
utushishi. Elyo amenshi ya mu chishi-
ma ichipi yalisankane na utushishi
ichishasuminishiwa kunpendwa ya
lubwe na utushishi ukusangwa mu-
menshi ya kunwa ichipimo cintu aka-
bungwe ka WHO na USEPA twa pi-
ma.
U kw ing fum a ku
k o w

Lusangwa mumenshi icho lusendwa na mu-
lamba wanfula uyo uuya mukuponesha mu-
fishima elyo na mu milonga ya menshi.
Elyo ututwine utumputawisha utwalubwe
(aluminium na iron) abantu balanwina kumo
mumenshi. Ifyo ifinga leta ubwafya kubumi
bwamuntu.. Limo tekunya fye mumenshi lelo
nokupemafye ululwine ulukungu lwa ulubwe
nangu utumputawisha twa ulubwe ukwikata
kunkanda yamuntu.. Utushishi tufuma muma-
la ya muntu nangu inama iya kwata umulopa
uwakaba. Utu utushishi tusendwa ukupitila
mumafisho (amafi).

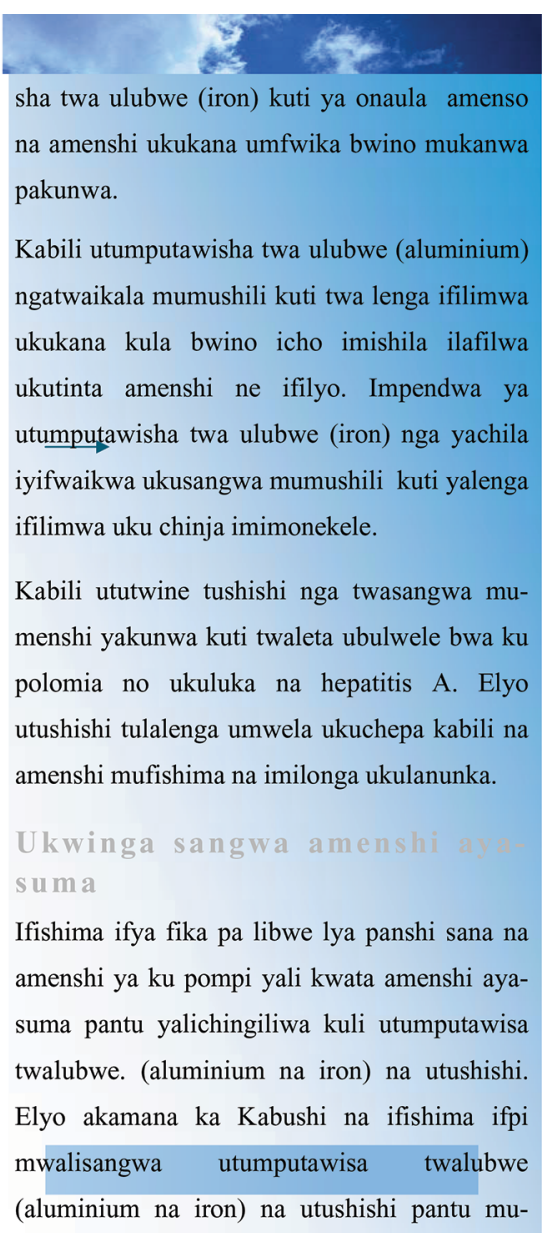

FIGURE 3. Back of Brochure used in Kaniki.

issues being faced which cannot be achieved by 'deposit' or 'transfer' methods of communication familiar to Western education modes [I I ].

Like the participants in Ndola, a number of scholars oppose depositing or transferring of knowledge as a method of learning, as it incapacitates people from being critical thinkers and taking action regarding an issue [II-I5]. Other Indigenous and critical writers emphasise the role of two-way discussion and storytelling as modes of communication that allow more creativity in thinking and planning $[6,16,17]$. Therefore this finding may have relevance beyond Ndola, while we recognise that our research is particular to Ndola.

In general, the participants expressed approval, surprise, and delight when Mando returned to their communities to share the water quality knowledge gained from Liddle's study. They said:
We are very happy that you have come in person. It is most helpful to come and discuss with us. We are able to freely ask questions, we did not only listen to you but you also listened to what we have to say about our water. We have learnt more and we now have a good understanding of the water issues we are facing (Focus group 3 ).

When given the opportunity to engage in a dialogue over the four methods used to share Liddle's water quality results with them, they preferred face-to-face discussion over video, brochure, or presentation, for the reason that it enabled them to reflect deeply, ask questions, and talk over concerns and mitigation options:

We would like to discuss the water issues in detail instead of just reading about it in the brochure. A video is an interesting way of communicating information but it is not the best because we cannot have the opportunity to discuss and educate each other (Focus group 2). 
The individuals who do not have the opportunity to read the brochure or watch the video may not believe us if we tell them. So, visiting us as you have done and discussed the water issues with us is better because we all have heard for ourselves [in person], we have asked questions, shared our understanding of water issues with you and we have also been educated in the process. Thank you so much (Focus group I).

You stood in front and gave a presentation of the water quality results, significant concerns, and mitigation options while we were seated listening. The presentation method reminds us of school. It is very formal and felt like you are in charge and we are here to receive information then ask questions at the end. We are sick and tired of being talked at, so we do not even pay attention (Focus group 2).

\section{CONCLUSION: COMMUNITIES AND THE DECOLONISING APPROACH}

While we approached access to results as a key step in decolonising scientific methods, based on our reading of indigenous methodologies, the Belmont Principles of ethical research established as long ago as 1978 state that all communities should benefit directly from research, rather than one community bearing the brunt of research for the benefit of others. Some researchers have explored this in relation to post-disaster research in Aotearoa New Zealand [5, I 8], for example, and there are plenty of discussions around the ethics of using available or vulnerable populations for scientific research without regard for their wellbeing, with recent shifts particularly in medical ethics [19]. Yet it seems clear that these ideas are not as universal as one might imagine, and each vulnerable group-we think here of women, Indigenous peoples, and minority peoples of colour-struggles for the realisation of these rights in their own context [20]. In this case study, we have understood our role as researchers as being part of the struggle to get water scientists to honour the rights of Indigenous and marginalised communities from which water samples have been taken.

In saying this, we do not mean to imply that Indigenous communities or participants such as those in Ndola are passive victims sitting around waiting for researchers to save them. Indeed, while the communities unanimously demanded the right to have water results returned to them, they also relied on their own knowledge and experiences of water in their areas to make their decisions about how to use that water. For example, the majority of the participants from the three communities decided to share the water resource knowledge with their neighbours and other community members who were not present, and these community members had differing levels of acceptance of the findings of Liddle's study and Mando's explanation of mitigation options.

One woman (69 years), who was born and still lives in Kabushi Township, expected the water quality results from the Kafubu River to be poor because some people throw garbage and contaminants in the river while others used it to wash clothes and do other water-related chores. She knew that the numerous pit latrines in this high-density area are a potential threat to their groundwater, and understood the bacterial risks involved in the use of water from the shallow wells mostly through her own experience and observation of illness. Even though the water quality results from Liddle's study showed that the shallow wells are relatively safe compared to the Kafubu River, she still said that she will not use water from those wells for drinking and cooking because she knows they are prone to bacterial contamination from the latrines. She insisted that she will continue to use water from the communal taps and boreholes because they are deeper and are better protected from contaminants. This shows that access to Liddle's findings confirmed individuals' suspicions which were based on experiences, while providing them with additional explanations of the likely source of contaminants. Yet the results were not accepted blindly, since it was recognised that Liddle's work was a snapshot in time and not representative of the long-term observations which local people had made in their own area.

It is clear from this case study that a decolonising approach is not just about returning findings or hard data to the community, but providing spaces of knowledge sharing and acknowledging local people's knowledge and its relationship to scientific knowledge. This is especially the case with groups traditionally overlooked by scientists, such as poorer people in villages without restricted access to water resources. Our findings show that a face-to-face approach where discussion is facilitated and valued is not just about mitigating against an extractive approach to research-it also provides opportunities for scientific researchers to moderate their 'expert' results and learn from local knowledge as well, reducing the power differential significantly.

Indeed, a truly decolonising scientific methodology would go further than this: many Indigenous scholars further state that research must contribute to self-determination 
and the benefit of the community $[7,2 \mathrm{I}]$, not only to the researcher and the researcher's community. For environmental scientists, this means engaging with Indigenous communities even earlier in the research process, in order to ensure that research methodologies are based on open, democratic, and equal relationships, where the rights, perspectives, knowledge, desires, needs, and concerns of people are valued, and culture and difference in power are appropriately considered in participation and communication.

\section{CASE STUDY QUESTIONS}

I. Why do water quality projects not usually go through ethics procedures?

2. What is 'extractive' research, and why is it associated with colonialism?

3. Why is returning water data to communities considered 'decolonising' research methodologies?

\section{AUTHOR CONTRIBUTIONS}

$\mathrm{MC}$ and $\mathrm{KD}$ conceived of the research design and methodology. MC carried out the fieldwork, data analysis, and writing of a draft under KD's supervision as part of a Masters in Water Resource Management at the University of Canterbury. KD re-structured, contributed writing, and edited the draft, with additional input from MC. Both authors contributed to revisions.

\section{ACKNOWLEDGMENTS}

We would like to thank Elizabeth Liddle for providing us with access to her water quality data in order to do this research. We also thank Ann Brower for helpful feedback on our draft. Kelly would also like to acknowledge Sarah Beaven for co-teaching the class in which this case study was presented.

\section{FUNDING}

The fieldwork for this project was funded by the Ministry of Foreign Affairs and Trade of New Zealand, and the Geography Department of the University of Canterbury.

\section{COMPETING INTERESTS}

The authors have no competing interests.

\section{SUPPLEMENTARY MATERIALS}

Slides: Returning water data to communities in Ndola, Zambia.

\section{REFERENCES}

I. Fernandez CV, Kodish E, Weijer C. Informing study participants of research results: an ethical imperative. IRB Ethics Hum Res. 2003;25(3): 1 2-19.

2. Leach M, Scoones I. Science and Citizenship in A Global Context. In: Gaventa J, editor. Science and Citizens: Globalization and the Challenge of Engagement. London: Zed Books; 2005. pp. I 5-42.

3. Edwards R, Mauthner M. Ethics and Feminist Research: Theory and Practise. In: Miller T, Birch M, Mauthner M, Jessop J, editors. Ethics in Qualitative Research. London, Thousand Oaks, New Delhi, Singapore: SAGE; 20 I 2. pp. I 4-28.

4. Scheyvens H, Scheyvens R, Murray WE. Working with Marginalised Vulnerable or Privileged Groups. In: Scheyvens R, editor. Development Fieldwork: A Practical Guide. 2nd ed. London: SAGE; 2014. pp. I 88-214.

5. Beaven S, Wilson T, Johnston L, Johnston D, Smith R. Research engagement after disasters: research coordination before, during, and after the $20 \mathrm{I}$ I-20I2 Canterbury earthquake sequence, New Zealand. Earthquake Spectra. 20 I 6;32: 71 3-735.

6. Tuhiwai Smith L. Decolonizing Methodologies: Research and Indigenous Peoples. London, New York, Dunedin: Zed Books \& University of Otago Press; 1999.

7. Chilisa B. Indigenous Research Methodologies. Thousand Oaks, London, New Delhi, Singapore: SAGE; 20 I I.

8. Nkhuwa DC, Mweemba C, Kabika J. Zambia: Country Water Resource Profile. NEPAD; 2013. Available: https://www.nepad.org/file-download/download/public/ I 4258 .

9. Water Aid. Where We Work: Zambia. [Web page]; 2016. Available: http://www.wateraid.org/where-we-work/page/zambia. Io. Liddle, E. S. (2014). Assessing the state of the water quality, the challenges to provision, and the associated water development considerations in Ndola, Zambia (Doctoral dissertation, University of Otago).

I I. Freire P. Education for Critical Consciousness. London: Bloomsbury Publishing; 1974.

I2. Beaulieu RJ. Action research: trends and variations. Can J Action Res. 2013;1 4: 29-39.

13. Kapoor I. The devil's in the theory: a critical assessment of Robert Chambers' work on participatory development. Third World Q. 2002;23(I): 101-1 I 7 .

14. Park P. People, knowledge, and change in participatory research. Manage Learn. 1999;30(2): 141-1 57.

i 5. Karlsen JI. Action Research as a Method. Reflections from a Program for Developing Methods and Competence. In: Whyte WF, editor. Participatory Action Research. Newbury Park: SAGE; I 99 I. pp. I 26-I 43.

16. Simmonds N. Transformative Maternities: Indigenous Stories as Resistance and Reclamation in Aotearoa New Zealand. In: 
Robertson M, Tsang P, editors. Everyday Knowledge, Education and Sustainable Futures. Singapore: Springer; 20 I 6. pp. 7 I -88.

17. Gibson K, Rose DB, Fincher R. Manifesto for Living in the Anthropocene. New York: Punctum Books; 2015.

1 8. Gaillard J, Gomez C. Post-disaster research: is there gold worth the rush? Opinion paper. Jàmbá J Disaster Risk Stud. 2015;7: I-6.
19. Paterson R. The Cartwright legacy: shifting the focus of attention from the doctor to the patient. $N Z \operatorname{Med} J$. 2010; 1 23: I 319 .

20. Brown MB, Guston DH. Science, democracy, and the right to research. Sci Eng Ethics. 2009; I 5: 35 I-366.

2r. Tuhiwai Smith LT. Decolonizing Methodologies: Research and Indigenous Peoples. 2nd ed. London: Zed Books; 20 I 2. 